\title{
A Survey on Digital Immigrants' Technology Usage and Practice in Teaching Digital Natives
}

\author{
Dipima Buragohain \\ Centre for International Languages, Universiti Malaysia Perlis \\ Ulu Pauh, Arau, 02600, Perlis, Malaysia \\ Tel: 60-111-518-9560Ｅ-mail: dipima@unimap.edu.my
}

Received: September 15, 2019 Accepted: October 15, 2019 Published: October 17, 2019

doi: 10.5296/ire.v8i1.15560

URL: https://doi.org/10.5296/ire.v8ii1.15560

\begin{abstract}
The widespread use of digital technologies by digital natives has put a considerable amount of pressure on their educators, who are mostly digital immigrants, to recognize the relevance of digital connectivity, learn new ways of thinking and processing information of the digital natives, and integrate it into their teaching environments. The current study looks into these aspects while discussing the technology usage and practice of digital immigrant educators in higher education. A survey was conducted with a structured questionnaire on the technology usage and teaching strategies implemented by the digital immigrant educators to teach digital natives in higher education. The findings reported that digital immigrant educators must be accustomed to the a) diverse needs of digital native students and b) use and applications of digital technologies in order to create and practice interactive and collaborative teaching environments.
\end{abstract}

Keywords: Digital natives, Digital immigrants, Teaching strategies, Interactive teaching and learning, Higher education

\section{Introduction}

'Digital natives', a term originally coined by Marc Prensky in 2001, is the generation born in the digital age characterized by the widespread adoption of digital technologies in their everyday lives (Chan \& Yee, 2009; Janzen, Perry, \& Edwards, 2012). This trait of the digital natives has further put a considerable amount of pressure on their educators who are mostly 'digital immigrants', another term by Prensky, or the generation born before the widespread adoption of digital technologies and less quick to pick up new technologies than digital natives. Digital natives are basically the 'native speakers' of the digital language. Digital immigrants as educators of digital natives are facing challenges of recognizing the relevance 
of digital connectivity, learning new ways of thinking and processing information of the digital natives, and integrating it into their teaching environments. The current study aims at looking into these aspects while discussing the technology usage and practice along with teaching strategies of educators in higher education for digital natives. It has conducted a survey among faculty members from the Engineering, Management and Humanities schools at two Malaysian public universities. Investigations of the survey highlight five aspects related to digital immigrants' technology usage and teaching strategies for digital natives including their: a) digital connectivity, b) familiarity with digital natives, c) technology use in classroom instruction, d) teaching strategies and e) learning engagement methods. The current study was undertaken with the following objectives:

- To investigate technology usage of digital immigrants as educators in higher education

- To explore technology practice by digital immigrants in teaching

- To examine their teaching strategies and approaches of learning engagement for digital natives

\section{Literature Review}

Teaching digital natives as students is one of the biggest challenges of educators in higher education who are mostly from the generation born before digital skills were adopted in their everyday lives, a generation coined as 'digital immigrants' by Marc Prensky in 2001. Some of the characteristics that differentiate digital immigrants from digital natives include the latter's relatively higher use of technology, online reading habit, interaction through social media (Kotz, 2016), multitasking proficiency and being team-orienteers (Koutropoulos, 2011). With digital natives consuming information from digital technologies everyday every time, traditional classroom teaching is no longer considered sufficient for engaging such students (Chan \& Yee, 2009). Researchers have addressed this issue by suggesting educators to learn, adopt and use new technologies for interacting with digital natives and engaging them in sustaining their interest as well as enhancing their learning experience and competency (Oliver \& Goerke, 2007; Chan \& Yee, 2009; Janzen, Perry, \& Edwards, 2012). Digital natives are technology savvy and avid readers of online information which is prevalent in their consumption of almost anything online. This further endorses their educators to understand, adjust and cater to learner engagement in technology with educational tools, and then implement those changes in their teaching styles (Kotz, 2016).

Use of technology in everyday life has changed the perception of communication not only in general but also in specific domains such as education. Students now prefer interactive classes with extra personal attention from their teachers (Kotz, 2016). As jugglers between different tasks at once, digital natives are very comfortable listening to music, watching the television and working on the computer or their smartphone at the same time (Elliot-Yeary, 2012). This generation is socially conscious, hungry for feedback, motivated to learn ways of reducing stress and increasing their marketability (Kotz, 2016). As frequent readers, digital natives are accustomed to learning and using new forms of digital technology to consume information. Digital immigrants as educators should be aware of these characteristic traits of digital natives while teaching them and learn to win their attention by delivering information using technologies such as web-based environments, virtual simulations and other interactive 


\section{Macrothink

materials (Chan \& Yee, 2009).

In terms of teaching methods and approaches, technology-driven classroom teaching is fast becoming a common practice in higher institutions. Effective teaching practices now refer to blended learning approach combined with traditional classroom learning and information communications technology (ICT). Different modes of delivery with web-based instruction can help students engage in learning in and beyond their classrooms.

\section{Research Design}

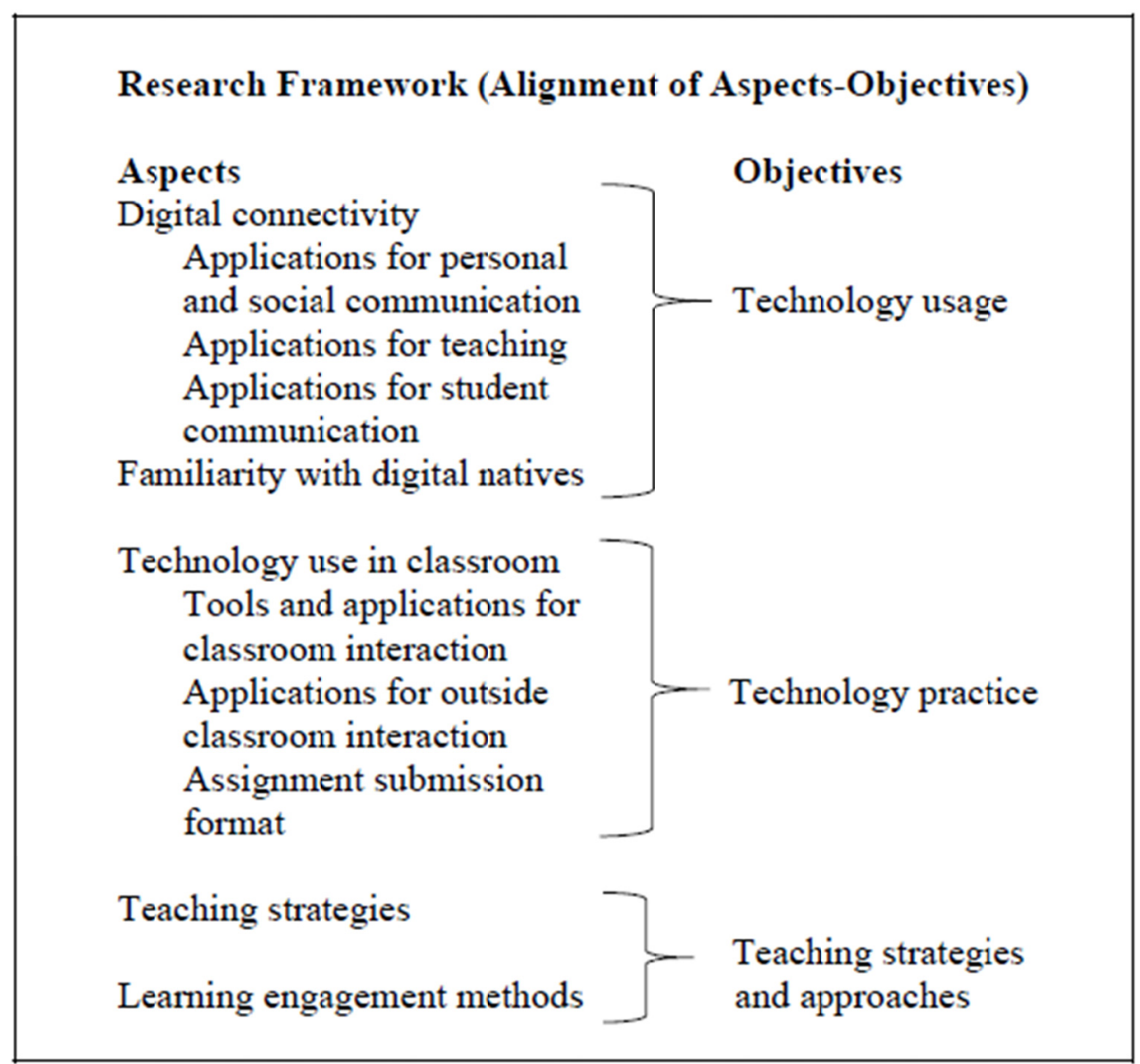

Figure 1. Research framework

The current study has conducted a survey on digital immigrant educators' technology usage and practice along with their teaching strategies for digital native students in two Malaysian public universities. A total of 50 lecturers, with an age range from 35 (or less) to 55 (or more), were chosen randomly from various departments and schools in the two universities teaching a variety of 16 subjects in the Engineering, Management and Humanities fields. The survey used a structured questionnaire on technology usage and teaching strategies implemented for educating digital natives in higher education. It aimed at eliciting information from the digital immigrants as educators particularly on their digital connectivity, familiarity with digital natives, technology use in classroom instruction, teaching strategies and learning engagement 


\section{Macrothink}

methods. Figure 1 above demonstrates the alignment of these aspects with the objectives of the study. Statistical Package for Social Sciences (SPSS) was used for analyzing data while descriptive statistics was used for discussing the findings.

\section{Findings and Discussion}

The current study has conducted a survey to investigate digital immigrants' technology usage and practice along with their teaching strategies to teach digital natives in higher education by highlighting five aspects related to their digital knowledge, use and strategies for teaching. The details are discussed below.

\subsection{Demographic Profiles}

Table 1. Demographic profiles of participants

\begin{tabular}{lll}
\hline Percentage (\%) & & \\
\hline Schools & Management & 40 \\
& Engineering & 36 \\
Education & Humanities & 24 \\
& PhD & 52 \\
Teaching experience (in years) & MTech/MSc/MA & 48 \\
& $>25$ & 10 \\
& $15-25$ & 20 \\
Age range & $5-15$ & 58 \\
& $<5$ & 12 \\
& $>55$ & 10 \\
& $45-55$ & 24 \\
& $35-45$ & 46 \\
\hline
\end{tabular}

Table 1 above includes the demographic details of participants in the current study. Educators teaching a variety of subjects in the areas of Engineering, Management and Humanities from two Malaysian universities were randomly chosen for the survey. Most of the participants had 5-15 years of teaching experience and belonged to the age group of 35-45 years, which are digital immigrants mostly born before the widespread use of digital technologies.

\subsection{Findings and Discussion}

Objective 1: Technology usage by digital immigrant educators

Table 2. Digital connectivity of digital immigrants

\begin{tabular}{lll}
\hline Frequency & & Valid Percent \\
\hline First computer & 23 & 46 \\
First email account & 25 & 50 \\
First social media account & 24 & 48 \\
\hline
\end{tabular}

In terms of digital connectivity, most of the participants in the survey had their first email 


\section{NI Macrothink}

accounts and social media accounts 15-20 years ago - a time when digital technologies had already been used widespread. However, participants purchased their first personal computers some 10-15 years ago with some of them informing they used the public computers at workplace or never used it at all before as it was not a prerequisite for classroom teaching before, as described in Table 2 above. Digital immigrants are not exposed to technology as much as digital natives due to which they find it relatively difficult to embrace and adjust to the constant changes with existing, new and emerging technologies (Woods, 2006).

Table 3. Applications for personal/social communication

\begin{tabular}{lll}
\hline Frequency & & Valid Percent \\
\hline Email & 39 & 78 \\
WhatsApp & 50 & 100 \\
Facebook & 41 & 82 \\
Instagram & 27 & 54 \\
Twitter & 16 & 32 \\
WeChat & 33 & 66 \\
YouTube & 12 & 24 \\
\hline
\end{tabular}

The survey found that 42 out of 50 participants have contributed to blogs or online discussion. In terms of technologies and applications, digital immigrants as educators prefer to use WhatsApp and Facebook for their personal or social communication, as mentioned in Table 3 above. Digital natives are natural collaborators (Kivunja, 2014) who believe in interaction. Since they are online most of the time, familiarity with digital applications for communication is relevant for educators.

Table 4. Applications for teaching

\begin{tabular}{lll}
\hline & Frequency & Valid Percent \\
\hline Email & 13 & 26 \\
Blog & 29 & 58 \\
Educational/reference websites & 32 & 64 \\
WhatsApp & 24 & 48 \\
Facebook & 11 & 22 \\
YouTube & 10 & 20 \\
\hline
\end{tabular}

In case of academic communication, digital immigrants are likely to use email and WhatsApp applications (100\%) along with WeChat at times (46\%). Digital immigrants as educators use various online applications for teaching while mostly using educational websites, blogs and even WhatsApp, as seen in Table 4 above. This is relevant for interacting with digital natives who are smarter and quicker than digital immigrants in learning through interaction and integrity (Kivunja, 2014). Digital natives turn online to communicate, understand and learn while they can change or create content. Therefore, using digital applications in teaching digital natives is relevant for digital immigrants as educators. This is also relevant for 
communicating with students (see Table 5).

Table 5. Applications for student communication

\begin{tabular}{lll}
\hline & Frequency & Valid Percent \\
\hline Email & 37 & 74 \\
WhatsApp & 50 & 100 \\
Facebook & 11 & 22 \\
Instagram & 13 & 26 \\
YouTube & 9 & 18 \\
\hline
\end{tabular}

As seen in Table 5 above, in terms of communicating with students, all educators use WhatsApp while some preferring email communication as well.

Table 6. Familiarity with digital natives

\begin{tabular}{ll}
\hline Frequency & Valid Percent \\
\hline I use technologies and applications to connect with my students. & 50100 \\
I give group assignments to my students. & 50100 \\
I encourage my students for and assign them self-directed learning. & 4284 \\
I encourage my students for peer study groups. & 3978 \\
I discuss new technologies with my students. & 2754 \\
\hline
\end{tabular}

In terms of familiarity with digital natives and their characteristics, behaviors and attitudes, educators try to connect with them through various technologies and applications (100\%), as shown in Table 7 above. This is particularly useful for students beyond classroom learning as digital natives are comfortable using online materials and applications to understand concepts and do their assignments, basically communicating without face-to-face interaction (Chan \& Yee, 2009). Digital natives spend a lot of time using digital devices for communication. Educators using such communication tools (see Table 5) can bridge the gap between them and students while creating an interactive and collaborative learning environment.

In the light of the findings above, the current study has reported that digital immigrant educators are not as exposed to new and emerging technologies as their digital native students. They prefer to use technology for communicating with students and in classroom as well; however, they do not consider it as a prerequisite for classroom teaching. With more and more technology implementation of digital natives in their personal, social and academic lives, digital immigrants should be more familiar with these technologies to connect with their students academically.

Objective 2. Technology practice by digital immigrants in teaching 


\section{NI Macrothink}

Table 7. Technology use in classroom instruction

\begin{tabular}{ll}
\hline Frequency & \multicolumn{1}{c}{ Valid Percent } \\
\hline I feel comfortable using technologies in my class. & 50100 \\
I am very proficient in using a variety of applications in my class. & 4386 \\
I often integrate technologies in my teaching activities. & 50100 \\
I often integrate technologies in my class assignments. & 3672 \\
\hline
\end{tabular}

When it comes to using technology in classroom instruction, digital immigrants as educators feel comfortable using technologies in class for various purposes, e.g., explaining concepts and topics, describing examples, or for presentation and assignment purpose. They often integrate technologies in teaching activities with a $100 \%$ response while most of them are proficient in using a variety of applications for classroom instruction, as seen in Table 6 above. It is important for educators to embed digital and technological content in their teaching to accommodate digital natives into knowledge construction through tools and applications they are familiar with (Kivunja, 2014).

Table 8. Tools and applications for classroom interaction

\begin{tabular}{lll}
\hline & Frequency & Valid Percent \\
\hline Textbook & 50 & 100 \\
PowerPoint slides & 50 & 100 \\
Whiteboard & 50 & 100 \\
Video & 44 & 88 \\
LCD projector & 50 & 100 \\
Online site/blog & 39 & 78 \\
\hline
\end{tabular}

Digital immigrants as educators are well-connected with digital natives as their students through digital technologies. The survey reported that they use LCD projectors, PowerPoint slides and videos in classroom interaction, as mentioned in Table 8 above. Knowledge of technology is crucial for educators in terms of classroom technology implementation and integration with student learning (Kotz, 2016). The use of technology in classroom can be optimized not only as a learning tool in general but also as a tool of instructional preparation and instructional delivery. Further, digital natives' daily use of technologies can be utilized by educators to promote collaborative and interactive learning.

Table 9. Applications for outside classroom interaction

\begin{tabular}{lll}
\hline & Frequency & Valid Percent \\
\hline Email & 38 & 76 \\
WhatsApp/text message & 50 & 100 \\
Online forum/blog & 42 & 84 \\
\hline
\end{tabular}

As shown in Table 9 above, the survey reported digital immigrants using technologies and 


\section{Ml Macrothink}

applications such as WhatsApp (100\%), blogs or online forums to connect with their students outside classrooms mainly for purposes including class announcements, asssignment updates, consultation updates and so on. A possible scope of future inquiry here is the aspect of language use in such interactions. The use of slangs and shortened forms of words is a common practice among digital natives. How digital immigrant educators encourage their students to understand netiquette and use language appropriately in their interaction is an interesting research idea but beyond the scope of the current study.

Table 10. Assignment submission format

\begin{tabular}{lll}
\hline & Frequency & Valid Percent \\
\hline Notebook & 50 & 100 \\
PowerPoint slide & 47 & 94 \\
Audio-visual & 47 & 94 \\
Email & 36 & 72 \\
Word/Excel file & 50 & 100 \\
\hline
\end{tabular}

The survey also reported that most educators prefer their students to submit assignments in various digital formats including word or excel files, PowerPoint, audio-visual or emails other than notebooks, as described in Table 10 above. Learning by reading only texts is not preferred by digital natives; they are used to learning through visuals and graphics. Since digital natives are relatively more familiar with technology use, digital immigrants as educators should know and practice how to use the computer, and electronic and digital tools to teach and reach their digital learners (Kivunja, 2014).

In the light of the findings above, the study has found that digital immigrants use various applications and tools in classroom to explain concepts and topics, examples and for assignments. Different digital formats are accepted for assignments in classroom teaching. Digital immigrants also prefer to use common applications to interact with their students outside classroom for assignment or class updates. As digital natives are familiar with using technology for almost everything, digital immigrants should be more aware of the technology usage and learn to find new ways of optimizing it for providing students with better learning experience.

Objective 3: Teaching strategies and approaches

Table 11. Teaching strategies and approaches

\begin{tabular}{lll}
\hline & Frequency & Valid Percent \\
\hline $\begin{array}{l}\text { I provide my students with clear background knowledge } \\
\text { of topics. }\end{array}$ & 100 \\
$\begin{array}{l}\text { I conduct group activities/discussions in class to explain } \\
\text { concepts. }\end{array}$ & 100 \\
$\begin{array}{l}\text { I encourage my students for self-directed and peer } 47 \\
\text { studies and problem-solving. }\end{array}$
\end{tabular}


I provide my students with clear instructions to solve 50 100 problems.

I provide my students with sufficient room for using and $\quad 50$ improving thinking and reasoning skills.

I work with individual students.

46

92

Educators focus on providing digital natives with complete background knowledge of topics and clear instructions of problem solving while engaging and encouraging them for group activities and peer studies to improve their cognitive and reasoning skills, as mentioned in Table 11 above. Digital natives are used to a huge amount of information which is mostly accessed by networking, meaning they are collaborators preferring not just individual activities but also collective ones to improve learning. To know as well as improve learning experience of the digital native students, digital immigrant educators should interact with them more frequently, teach them critical thinking skills for knowledge construction, motivate them for self-directed and collaborative learning and introduce them to more and more web-based assignments (Kivunja, 2014). Embedding teaching strattegies pertaining to digital technologies into pedagogical practices is crucial in facilitating learning engagement and learning experience of digital natives.

Table 12. Learning engagements

\begin{tabular}{lll}
\hline & Frequency & Valid Percent \\
\hline Small-group activities & 31 & 62 \\
Sometimes & 19 & 38 \\
Almost in every class & & \\
Proficiency-based assignments & 38 & 76 \\
Sometimes & 12 & 24 \\
Almost in every class & & \\
Classroom activities/topic suggestions & 15 & 30 \\
Never & 26 & 52 \\
Sometimes & 9 & 18 \\
Almost in every class & & \\
Feedback on homework & 50 & 100 \\
Almost in every class & & 100 \\
Self-evaluation and reflection & 50 & \\
Almost in every class & & \\
\hline
\end{tabular}

In terms of learning engagement, educators always provide feedback on students' homework while encouraging them to self-evaluate and reflect, as shown in Table 12 above. Use of digital technologies in such interactions is instrumental (Chan \& Yee, 2009). Educators can manage and maintain online discussion forums for such interactions encouraging active participation of digital natives who spend most of their time on online social communication. Students are given assignments catering to the requirements of their proficiency level while 


\section{Macrothink}

they are encouraged to work in small groups for problem solving as well as to suggest classroom activities and topics (see Table 12). Digital natives are likely to learn from online digital sources by means of online games, blogs, wikis while developing skills for digital fluency (Kivunja, 2014). Educators can incorporate various digitally oriented activities for learner engagement including online games and videos, and thus provide digital natives with the environment for learning (Chan \& Yee, 2009).

In the light of the findings above, the current study has reported that digital immigrants provide adequate learning environment to students while encouraging and engaging them to improve their comprehension and problem-solving skills. Digital immigrants should develop their digital fluency in order to cater to students' learning needs. Utilizing digital technologies and various digital platforms is the need of the hour to improve student engagement and learning which further enhances interactive learning environment.

\section{Conclusion and Recommendations}

Technology has changed the way information is processed and constructed as knowledge base. It has also changed the ways teaching and learning are imparted making progressive and innovative moves for more interactive, collaborative and web-based learning approaches. Digital immigrants as educators play a crucial role in imparting interactive and collaborative teaching and learning environments for digital native students. The current study has conducted a survey of digital immigrants' technology usage and practice along with their teaching strategies to teach digital natives. However, the study has its limitations. It has limited participants - only the lecturers chosen for the survey. Moreover, use of digital technologies is not discussed in detail since the participant educators are not frequent users of those technologies. Gender aspect is not considered for the study and participants are selected randomly. Further, approaches and strategies of acquiring digital competences by digital immigrant educators could be investigated as another potential scope of future research. Use of language in various digital platforms can be considered as another potential research which could investigate how digital immigrants use these platforms to educate language use and its appropriateness. Digital trends will keep updating the applications due to which digital immigrants as educators will need to stay updated at the same pace of their digital native students. Digital immigrant educators should emphasize on making more connections with their students by means of learning, implementing and practicing digital technologies and applications in teaching and learning environments, and thus enhancing student learning. Technology is ever-growing and ever-innovating. New and emerging technologies make way for infinite access to information which can help digital immigrant educators create numerous possibilities of inside and outside classroom learning activities and interactions for digital native students. This will further enhance learning experience for both digital immigrants and their digital native students while merging the differences between these two generations.

\section{Conflict of interest statement:}

The author hereby declares that there is no conflict of interest involved in this manuscript.

\section{Funding statement:}

There is no funding involved in this manuscript. 


\section{Nacrothink}

International Research in Education

ISSN 2327-5499

2020, Vol. 8, No. 1

\section{References}

Brown, C., \& Czerniewicz, L. (2010). Debunking the 'digital native': Beyond digital apartheid, towards digital democracy. Journal of Computer Assisted Learning, 26, 357-369. https://doi.org/10.1111/j.1365-2729.2010.00369.x

Chan, Y. M., \& Yee, H. S. S. (2009). Classroom conduct for digital natives learning in higher educational settings. Proceedings of the $2^{\text {nd }}$ International Conference of Teaching and Learning (ICTL 2009).

Cornu, B. (2011). Digital natives: How do they learn? How to teach them? Moscow: UNESCO Institute for Information Technologies in Education.

Elliot-Yeary, S. (2012). Generation Y - The Millennial Generation. Generational Guru. http://generationalguru.com/2012/02/generation-y-the-millennial-generation

Janzen, K. J., Perry, B., \& Edwards, M. (2012). Engaging Students: Strategies for Digital Natives. Academic Exchange Quarterly, 16(3), 116-123.

Jones, C., \& Shao, B. (2011). The net generation and digital natives: Implications for higher education. York: Higher Education Academy.

Kotz, P. E. (2016). Reaching the millennial generation in the classroom. Universal Journal of Educational Research, 4(5), 1163-1166. https://doi.org/10.13189/ujer.2016.040528

Kivunja, C. (2014). Theoretical perspectives of how digital natives learn. International Journal of Higher Education, 3(1), 94-109. https://doi.org/10.5430/ijhe.v3n1p94

Koutropoulos, A. (2011). Digital natives: Ten years after. MERLOT Journal of Online Learning and Teaching, 7(4), 525-538.

Martin, E. M. (2011). Digital natives and digital immigrants: Teaching with technology. PhD Thesis, Northeastern University, Boston.

Oliver, B., \& Goerke, V. (2007). Australian undergraduates' use and ownership of emerging technologies: Implications and opportunities for creating engaging learning experiences for the Net Generation. Australasian Journal of Educational Technology, 23(2), 171-186. https://doi.org/10.14742/ajet.1263

Prensky, M. (2010). Teaching digital natives: Partnering for real learning. California: Corwin Press.

Thompson, P. M. (2012). The popular profile of the digital learner: Technology use patterns and approaches to learning. $\mathrm{PhD}$ Thesis, Michigan State University, Michigan.

Woods, R. (2006). The next step in brain evolution. The Sunday Times. http://entertainment.timesonline.co.uk/tol/arts_and_entertainment/article683193.ece?token=n ull\&offset $=0 \&$ page $=1$

\section{APPENDIX}

Questionnaire on Technology Usage and Teaching Strategies for Digital Natives Demographic profile

1. Your highest level of education:

2. Subject(s) you teach: 
3. Teaching hours per week:

4. Number of teaching years:

5. Year of birth:

\section{Digital connectivity}

1. When did you get your first computer?

2. Your first email account?

3. Your first social networking account?

4. Have you ever contributed to online discussion or blog?

5. Technologies and applications that you use:

a. For personal/social communication

b. For official communication

c. For teaching

d. For communicating with students

\section{Familiarity with digital natives}

Consider the following statements for yourself, choose Yes or No. Strike off the other option.

1. I use technologies and applications to connect with my students. Yes / No

2. I give group assignments to my students.

Yes / No

3. I encourage and assign them self-directed learning.

Yes / No

4. I encourage them for peer study groups.

Yes / No

5. I discuss new technologies with my students.

Yes / No

\section{Technology in classroom instruction}

1. In what ways are you using technology for classroom instruction?

Consider the following statements for yourself, write $\mathbf{T}$ if they are TRUE.

2. I feel comfortable using technologies in my class.

3. I am very proficient in using a variety of applications in my class.

4. I often integrate technologies in my teaching activities.

5. I often integrate technologies in class assignments.

\section{Teaching strategies}

Provide your answer for the following. (You can circle more than one answer.)

1. I stay connected with my students through:

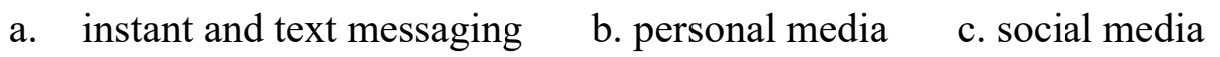

2. For classroom discussion, I use:
a. textbooks
b. PowerPoint slides
c. whiteboard
d. videos

e. LCD projector

f. online sites/blogs

3. For discussion outside classroom, I use:

$\begin{array}{ll}\text { a. emails } & \text { b. WhatsApp/text messages c. blogs/online forums }\end{array}$ 


\section{Macrothink

4. I accept assignment submission in the form of:

a. notebooks b. PowerPoint slides c. audio-visual d. emails

f. word/excel files

Consider the following statements for yourself, choose Yes or No. Strike off the other option.

5. I provide my students with clear background knowledge of topics.

Yes / No

6. I conduct group activities/discussion in class for explaining concepts.

Yes / No

7. I encourage my students to do self-directed and peer studies and find solutions to problems on their own.

Yes / No

8. I provide my students with clear instructions to solve problems.

Yes / No

9. I provide my students with sufficient room for using and improving thinking and reasoning skills.

Yes / No

10. I work with individual students.

Yes / No

\section{Learning engagement}

Provide your answer for the following.

1. I allow my students to work in small groups to come up with a joint solution to a problem or task.
a. never
b. sometimes
c. in almost every class
2. I assign different work to my students depending on their difficulty levels.
a. never b. sometimes c. in almost every class
3. I ask my students to suggest or to help plan classroom activities or topics.
a. never b. sometimes c. in almost every class
4. I review my students' homework and give necessary feedback.
a. never b. sometimes c. in almost every class
5. I ensure my students evaluate and reflect upon their own work.
a. never b. sometimes c. in almost every class

\section{Copyright Disclaimer}

Copyright reserved by the authors.

This article is an open-access article distributed under the terms and conditions of the Creative Commons Attribution license (http://creativecommons.org/licenses/by/3.0/). 